\title{
BioEd 2004: Biology, Sustainable Development, Ethics and Citizenship
}

\author{
18 September 2004 \\ Rio de Janeiro, Brazil \\ www.iubs.org/test/BioEd\%202004/frBioEd2004.htm.
}

Organized by the International Union of Biological Sciences Commission for Biological Education

With the cosponsorship of Fiocruz Foundation, IUBS, UNESCO, and the LDES, University of Geneva

To address the urgent questions of today, the most extensive possible debate is needed. The International Conference, BioEd 2004: Biological Education, Sustainable Development, Ethics and Citizenship, aims to provide such a forum.

\section{CONFERENCE GOALS}

- Explore the linkages among biological sciences, the environment, sustainable development, and society

- Promote bioliteracy and biology education reforms that integrate biology, sustainability, health, well-being, ethics, and citizenship

- Make recommendations for improving biology education worldwide in support of the UN Decade of Education for Sustainability, adopted for 2005-2015.

\section{CONFERENCE OBJECTIVES}

- Prepare an agenda for biological education in sustainable development, ethics, and citizenship

- Develop guidelines for implementing this agenda in developed and developing countries

- Involve leaders in science and society in the full range of the educational enterprise, from formal (intermediate and secondary schools, colleges, and graduate institutions) to informal, including public education, and training in environmental education, biological education, agricultural education, health education, and engineering education

- Address the question of identifying essential knowledge about the environment, sustainability, health, and wellbeing

- Address the roles of science and values in education, while exploring the use of new educational technologies and pedagogical methods

- Explore and evaluate the diversity of approaches and themes, encouraging participants to discover the shared ground of different themes and approaches
- Make recommendations on how to develop bioliteracy, with special reference to sustainability, ethics, and citizenship

- Prepare a report and distribute it widely, via hardcopy, the Web, and briefings and presentations to policy and decision makers at national and international levels.

\section{PARTICIPANTS}

The Conference will bring together approximately 300-500 bioscientists, biology educators and teacher-trainers, policymakers, business people, and media specialists, as well as philosophers, theologians, and ethicists. Participants from around the world will be invited to report on their research, experiments, and practical and empirical results and demonstrate educational materials and methodologies (posters, videos, exhibits, theater, etc.).

- Biological education, health, and well-being

- Biological education, environment, and sustainability

- Biological education, agriculture, nutrition, and food security

- Biological education in the modern age of information and communication technologies

- Biological education, ethics, and citizenship

Working groups will be established, involving chair persons and reporters of various symposia and workshops to draw up conclusions and recommendations for adoption at the final plenary session of the conference.

\section{ORGANIZING COMMITTEE \\ Michael Atchia Mauritius \& IUBS CBE/Former Chairman \\ Erwin Beck Germany \& IUBS \\ Pierre Clément France, University of Lyon}




$\begin{array}{ll}\text { André Giordan } & \begin{array}{c}\text { France/Switzerland, IUBS CBE } \\ \text { Chairman, LDES, University } \\ \text { of Geneva } \\ \text { Brazil, MMA, Vice President, IUBS } \\ \text { Brazil, Fondacao Oswaldo Cruz, Rio } \\ \text { de Janeiro }\end{array} \\ \begin{array}{l}\text { Danielle Grynzspan } \\ \text { Costa Rica, Chief, Science } \\ \text { Erlando Rose Hall }\end{array} & \begin{array}{l}\text { Eduation Division, UNESCO } \\ \text { Motonori Hoshi }\end{array} \\ \begin{array}{l}\text { Myriam Krasylchik } \\ \text { Keiko Nakamura }\end{array} & \begin{array}{l}\text { Brazil, University of Sao Paulo } \\ \text { Japan, IUBS CBE }\end{array}\end{array}$

\author{
N.M. Ramaswamy India \\ Faqir Vohra Malaysia, IUBS CBE \\ Wake Marvalee USA \& IUBS \\ Talal Younès Lebanon/France \& IUBS Executive \\ Director
}

Those interested in taking part in the BioEd 2004 conference may find information at the IUBS-CBE Web site: www.iubs.org/test/BioEd\%202004/frBioEd2004.htm.

For further details, please contact Faqir Vohra, SecretaryGeneral, CBE-IUBS, at fcvohra1@comcast.net. 